\title{
The Effects of Ethanol Extract and Ethyl Acetate Fractionation of Sechium Edule Jacq. Swartz on Triglyceride Levels in Male Rats with Type 2 Diabetes Mellitus
}

\author{
Jekson Martiar Siahaan'), Endy Julianto²), Hendrika Andriana Silitonga3) \\ 1)Department of Physiology, Faculty of Medicine, Universitas Methodist Indonesia \\ 2) Department of Parasitology, Faculty of Medicine, Universitas Methodist Indonesia \\ 3)Department of Histology, Faculty of Medicine, Universitas Methodist Indonesia
}

\begin{abstract}
Background: The prevalence of diabetes mellitus (DM) from year to year is increasing. Hyperglycemia that occurs in DM is caused by oxidative stress that damages pancreatic $\beta$ cells. This situation can be controlled with synthetic hypoglycemic drugs, but it requires high medical costs. Therefore, alternative therapies that are easily available, relatively inexpensive, have potential antihypoglycemia and anti-cholesterolemia which is found in conjoined flasks (Sechium edule (Jacq.) Swartz) which contains flavonoids are needed. The purpose of this study was to analyze the effectiveness of ethanol extract and fractionation of ethyl acetate extracts of Sami (pumpkin) (Sechium edule (Jacq.) Swartz) as anti-hipoglycemia and anti-hypertriglycerides in white male wistar rats (Rattus novergius sp.) induced by STZ-NA-HFDD.

Subjects and Method: A randomized controlled trial was conducted to assess the effectiveness of ethanol extract and fractionation of pumpkin fruit ethyl acetate extract. The sample included white male wistar rats (Rattus novergius sp.) Hyperglycemia induced by STZ-NA-HFD. The dependent variable was triglyceride levels. The independent variables were administration of ethanol extract and fractionation of pumpkin fruit ethyl acetate extract.

Results: Ethyl acetate fraction $45 \mathrm{mg} / \mathrm{kgBW}$ better reduce triglyceride levels but statistically does not have significant differences between groups.

Conclusion: The group that received Metformin and the group that was given ethanol extract 45 $\mathrm{mg} / \mathrm{kgBW}$ had lower triglyceride levels compared to the other therapy and control groups.
\end{abstract}

Keywords: Hipertrigliseridemia, diabetes mellitus, STZ-NA-HFD

\section{Correspondence:}

Jekson Martiar Siahaan. Department of Physiology, Faculty of Medicine, Universitas Methodist Indonesia. Jl. Setia Budi Pasar II Tj. Sari, Medan 20132, North Sumatera. Email: Jekson.siahaan.sked@gmail.com

\section{BACKGROUND}

Diabetes Mellitus (DM) has become the 10 biggest diseases that cause death worldwide and includes 3 other non-communicable diseases such as heart disease, cancer and respiratory disease. According to the International Diabetes Federation (IDF), in 2045, 695 million sufferers aged 18-99 years, as many as 629 million sufferers at the age of 20-79 years will suffer from DM (IDF, 2017). In 2015, the proportion of deaths in Indonesia due to diabetes reached 6\% (WHO, 2016).

The state of hyperglycemia can be modeled in experimental animals by using streptozotocin which stimulates the formation of free radicals in the mitochondria resulting in destruction of pancreatic $\beta$ cells (Cheng et al., 2017), so that destruction is not total, nicotinamide administration partially protects pancreatic $\beta$ cells (Kishore et al. , 2017). The addition of high fat intake in mice and changing the incoming calories 
more than the outgoing can trigger an increase in triglycerides and glucose levels resulting in insulin resistance (Skovsø, 2014). Mice induced by streptozotocin (STZ) will experience increased lipids through adequate absorption of glucose, sucrose, and triglycerides through the small intestine so that the villous epithelium experiences hyperplasia which will more quickly absorb all the fat nutrients from the small intestine (Omae et al., 2006; Hartz at al., 2018). There are 3 mechanisms of hyper-lipidemia in type 2 DM namely: first, insulin resistance causes uncontrolled triglyceride lipolysis in adipocytes and myocytes so that fatty acids return to the liver and stimulate the liver to produce very low density lipoprotein (VLDL), secondly the liver fails to degrade apoliprotein which indirectly causes the overproduction of apolipoprotein B (apoB) and VLDL, thirdly the expression of CIII apoliporotein in insulin resistance contributes to over production of VLDL. Increased lipid levels correlate with the incidence of cardiovascular disease. The adverse effects of DM can be controlled by using conventional medicines so far, but the health BPJS incurred DM medical expenses of Rp 9.2 trillion (BPJS, 2017). Surely it will be an economic burden so that an economical and efficacious therapy is needed, derived from natural ingredients containing flavonoids, has the potential as an antihipoglycemia and antihyperlipide$\mathrm{mia}$, one of which is found in chayote (Sechiumedule (Jacq.) Swartz). Siahaan et al. (2016) and Siahaan et al. (2017) showed that plant ethanol extract was able to reduce blood sugar levels (KGD) and oxidative stress and improve the diameter of mice pancreas $\beta$ cells. The biological effects of flavonoids Sechiumedule (Jacq.) Swartz are anti-hyperglycemic, anti-gastric ulcer (Firdous et al., 2012; Sateesh et al., 2012), cell anti-proliferative (Salazar et al., 2017), anti-colesterolemia (Listianasari, 2017) even its root extract is used as an antihypertensive (Earl et al., 2014). The many benefits of conjoined pumpkin but have not been studied intensively. Though these alternative drugs are easy to obtain, relatively inexpensive compared to synthetic oral hypoglycemia drugs. It would be very useful to anticipate the high cost of treatment given the increasing number of people with DM in the future.

\section{SUBJECTS AND METHOD \\ 1. Study Design \\ A randomized controlled trial was con- ducted to assess the effectiveness of ethanol extract and fractionation of pumpkin fruit ethyl acetate extract. The study was con- ducted at the Integrated Laboratory of the Faculty of Medicine, Methodist University of Indonesia and the Medan Medilab clinical laboratory.}

\section{Study Sample}

The sample included male white Wistar rats (Rattus novergius sp.) Hyperglycemia induced by STZ-NA-HFD. The inclusion criteria were 2.5 - 3 months of age, body weight of 180-220 grams, male and healthy condition (active and not disabled). Male rats with $\mathrm{KGD}<250 \mathrm{mg} / \mathrm{dl}$ will be ruled out and the Test Drop criteria will be applied if the subjects suffer from illness or death so that they do not meet the research procedure in which it takes 21 days.

\section{Study Variables}

The dependent variable was triglyceride. The independent variables were administration of ethanol extract and fractionation of pumpkin fruit ethyl acetate extract.

\section{RESULTS}

The triglyceride levels of male rats given extract for 21 days can be seen in Table 1.

Table 1 shows that the lowest triglyceride levels were in group $\mathrm{K}$ which 
received Metformin $40.5 \mathrm{mg} / \mathrm{kgBW}$, p.o followed by group $\mathrm{E}$ who were given ethanol extract of squash $45 \mathrm{mg} / \mathrm{kgBW}$, p.o but statistically there were no significant differences between groups.

Table 1. Rat Triglyceride Levels

\begin{tabular}{|c|c|c|c|}
\hline \multirow[t]{2}{*}{ Group } & \multicolumn{2}{|c|}{ Triglyceride } & \multirow[t]{2}{*}{$\mathbf{p}$} \\
\hline & Mean & SD & \\
\hline $\mathbf{A}$ & 65.98 & 8.31 & \\
\hline B & 117.85 & 29.09 & \\
\hline C & 147.78 & 106.20 & \\
\hline D & 77.76 & 12.48 & \\
\hline $\mathbf{E}$ & 65.77 & 12.65 & 0.124 \\
\hline $\mathbf{F}$ & 86.38 & 30.28 & \\
\hline $\mathbf{G}$ & 104.64 & 38.83 & \\
\hline $\mathbf{H}$ & 70.08 & 24.20 & \\
\hline I & 105.87 & $25 \cdot 30$ & \\
\hline $\mathbf{J}$ & 68.89 & 12.97 & \\
\hline $\mathbf{K}$ & 60.71 & 21.43 & \\
\hline
\end{tabular}

A: negative control (normal), B: Positive control, induced Streptozotocin $50 \mathrm{mg} / \mathrm{kgBW}+$ nicotinamide (120 mg/ kg), C: positive control, induced Streptozotocin $45 \mathrm{mg} / \mathrm{kgBB}+\mathrm{HFD}$, D: positive control, induced nicotinamide $110 \mathrm{mg} / \mathrm{kgBW}+\mathrm{HFD}$, E: Streptozotocin-induced treatment group $45 \mathrm{mg} / \mathrm{KgBW}+$ nicotinamide $110 \mathrm{mg} / \mathrm{KgBW}+$ HFD with ethanol extract of conjoined pumpkin fruit $45 \mathrm{mg} / \mathrm{kgBW}$, po, F: the treatment group induced by Streptozotocin 45 $\mathrm{mg} / \mathrm{KgBW}+\mathrm{HFD}$ with ethanol extract of conjoined pumpkin fruit $45 \mathrm{mg} / \mathrm{kgBW}$, po, $\mathrm{F}$ : the treatment group induced by Streptozotocin $45 \mathrm{mg} / \mathrm{KgBW}+$ nicotinamide $110 \mathrm{mg} / \mathrm{KgBW}+\mathrm{HFD}$ with ethanolic extract of chayote $100 \mathrm{mg} / \mathrm{kgBB}$, po, G: Streptozotocin-induced treatment group $45 \mathrm{mg} / \mathrm{KgBW}+$ nicotinamide $110 \mathrm{mg} / \mathrm{KgBW}+\mathrm{HFD}$ with ethanol extract of pumpkin fruit 150 $\mathrm{mg} / \mathrm{kgB}$, po, $\mathrm{H}$ : treatment group induced $45 \mathrm{mg} / \mathrm{KgBW}+$ nicotinamide $110 \mathrm{mg} / \mathrm{KgBB}+\mathrm{HFD}$ with fractionation of ethyl acetate conjoined pumpkin fruit $45 \mathrm{mg} / \mathrm{kgBB}$, po, I: treatment group induced Streptozotocin $45 \mathrm{mg} / \mathrm{KgBW}$ + nicotinamide $110 \mathrm{mg} / \mathrm{kgBW}+$ HFD with ethyl acetate fractionation of conjoined pumpkin $100 \mathrm{mg} / \mathrm{kgBB}$, po, J: group of the treatment was induced Streptozotocin $45 \mathrm{mg} / \mathrm{KgBW}$ + nicotinamide $110 \mathrm{mg} / \mathrm{KgBW}+$ HFD with fractionation of ethyl acetate conjoined pumpkin fruit $150 \mathrm{mg} / \mathrm{kgBW}$, po, K: the treatment group was induced Streptozotocin $45 \mathrm{mg} / \mathrm{KgBW}$ + nicotinamide $110 \mathrm{mg} / \mathrm{KGB}$ + meth $40.5 \mathrm{mg} / \mathrm{kgBW}$ (Perkeni, 2015).

\section{DISCUSSION}

Insulin resistance that occurs in diabetes mellitus causes changes in plasma lipoprotein in the form of hypertriglyceridemia, a decrease in plasma high density lipoprotein (HDL) cholesterol, low density lipoprotein (LDL) to be smaller, known as VLDL, more atherogenic (Goldberg, 2001). In this study all control groups continued to experience hypertriglyceridemia, this proves that this research method by giving STZ $45 \mathrm{mg} /$ $\mathrm{KgBW}, \mathrm{NA} 110 \mathrm{mg} / \mathrm{HgBW}$ and HFD is able to increase lipids in experimental animals, this study is also in line with $\mathrm{He}$, L where the experimental animals are modeled DM type 1 experiencing hypertriglyceremia and hypercholesterolemia (He et al., 2015).

The group given ethanol extract 45 $\mathrm{mg} / \mathrm{kgBW}$ was able to reduce triglycerides lower than the negative control group who did not get induction, but metformin had a better antihyperlipidemia effect than ethanol extract although statistically had no difference. Metformin in addition to being an antihyperglycaemia that works extrapankreas inhibits gluconeogenesis without stimulating insulin production (Zhang, et al., 2018) also acts as an antihyperlipidemia by disrupting lipogenesis (Rena, et al., 2017). 
Flavonoids in ethanol extract are powerful polyphenols and antioxidants, able to reduce serum lipid and cholesterol levels to prevent atheroscleosis. Wu et al., (2014) investigated the extracts of shoot polyphenols Sechiumedule (Jacq.) Swartz was able to stimulate lipolysis through AMP-activating protein kinase (AMPK) by increasing catabolism and disrupting the activity of enzymes that play an important role in lipid metabolism such as HMG-CoA reductase (AMPK) HMGCoR) and (fatty acid synthase) FAS.

This study is also in line with Neeraja et al. which shows that ethanol extract can reduce total cholesterol, triglyceride, LDL and VLDL serum levels, but there is a difference inNeeraja's study, the extract dose of $200 \mathrm{mg} / \mathrm{KgBW}$ is better at reducing serum lipid levels and has significant differrences between groups (Neeraja, 2015). Listianasari et al. (2017) investigated pumpkin fruit juice containing flavonoids and phenols to reduce serum triglierides. Flavonoids increase lipoprotein lipase activity while phenols work in the liver and intestine to inhibit lipoprotein secretion, inhibit the process of esterification and synthesis of Apo B-48 and Apo B-100 so that blood triglyceride levels fall.

\section{ACKNOWLEDGEMENT}

This research was funded by the Directorate of Higher Education DRPM in 2018/2019 through a novice lecturer research program. The researchers expressed their gratitude for the trust given to the team.

\begin{tabular}{c}
\hline REFERENCE \\
\hline BPJS (2017). Tangkis risiko kardiometa- \\
bolik dengan optimalisasi PROLANIS \\
(Counter cardiometabolic risk by \\
optimizing PROLANIS). Available at: \\
https://www.bpjs-kesehatan.go.id/-
\end{tabular}

bpjs/index.php/post/read/2017/536/ Avoid-Cardiometabolic-by-Optimalized-PROLANIS

Cheng Y, Shen J, Ren W, Hao H, Xie Z, Liu J, et al. (2017). Mild hyperglycemia triggered islet function recovery in streptozotocin-induced insulin-deficient diabetic rats. J Diabetes Investig. 8(1): 44-55.

Earl GL, Ramos RR, Zamilpa A, Ruiz MH, Salgado, Gabriela R, et al. (2014). Extracts and fractions from edible roots of Sechium edule (Jacq.) Sw. with antihypertensive activity. EvidenceBased Complementary and Alternative Medicine.

Firdous SM, Sravanthi K, Debnath R, Neeraja K (2012). Protective effect of ethanolic extract and its ethylacetate and n-butanol fractions of Sechium edulefruits against carbon tetrachloride induced hepatic injury in rats. International Journal of Pharmacy and Pharmaceutical Sciences. 4(1): 354-359.

Gholipour S, Shomali T, Kopaei MR (2018). Anti-hypertriglyceridemic activity of cornus mas in diabetic rats. Journal of Clinical and Diagnostic Research. 12(8): FCo1-FCo5 doi: 10.786o/JC$\mathrm{DR} / 2018 / 32161.11848$

GoldbergIJ (2001). Diabetic dyslipidemia: Causes and consequences. The Journal of Clinical Endocrinology \& Metabolism, 86(3), 965-971. doi: 10.1210/jcem.86.3.7304

Hartz JC, de Ferranti S, Gidding S (2018). Hypertriglyceridemia in Diabetes Mellitus: Implications for Pediatric Care. Journal of the Endocrine Society, 2(6): 497-512. doi: 10.1210/js.2018-00079.

He L, Hao L, Fu X, Huang M, Li R (2015). Severe hypertriglyceridemia and hypercholesterolemia accelerating renal 
injury: A novel model of type 1 diabetic hamsters induced by short-term high-fat/high-cholesterol diet and low-dose streptozotocin. BMC Nephrology,16(1). doi: 10.1186/s12882015-0041-5.

IDF (2017). International diabetes federation diabetes atlas - 8thEdition. Available at http://www.diabetesatlas.org/.

Kishore L, Kajal A, Kaur N (2017). Role of Nicotinamide in streptozotocin induced diabetes in Animal Models. J Endocrinol Thyroid Res. 2(1).

Listianasari Y, Dirgahayu P, Wasita B, Nuhriawangsa AMP (2017). Efektivitas pemberian jus labu siam [Sechium edule] terhadap profil lipid tikus [Rattus novergicus] (Effectiveness of administration of conjoined pumpkin juice [Sechiumedule] on the lipid profile of mice [Rattus novergicus].). Model Hiperlipidemia.Penelitian Gizi dan Makanan, 40 (1): 35-43

Omae T, Shimamoto C, Hiraike Y, Kanemitsu N, Iwakura K, Nakanishi Y, et al. (2006). Hyperlipidemia and fat absorption in model rats with type 2 diabetes mellitus. Bulletin of the Osaka Medical College. 52(2):45-58

Rena G, Hardie DG, Pearson ER (2017).The mechanisms of action of metformin. Diabetologia, 60(9): 1577-1585. doi: 10.1007/s00125-017-4342-z

Salazar-Aguilar S, Ruiz-Posadas L, CadenaIñiguez J, Soto-Hernández M, Santiago-Osorio E, Aguiñiga-Sánchez I, et al. (2017). Sechium edule (Jacq.) Swartz, a New Cultivar with Antiproliferative Potential in a Human Cervical Cancer HeLa Cell Line. Nutrients, 9(8): 798. doi: 10.3390/nu9o80798
Sateesh G, Hussaini SF, Kumar GS, Rao BSS (2012). Anti-ulcer activity of sechium edule ethanolic fruit extract. The Pharma Innovation. 1 (5).

Siahaan JM, Urip H, Ricke L (2016). Effect of ethanol extract of chayote (Sechium edule.Jacq.Swartz) on the activity of glutathione peroxide (GPx) in house mice (Musmusculus L) strain DD webster hyperglycemia induced by streptozotocin (STZ).Indonesian Journal of Medicine. 1(1): 44-49.

Siahaan JM (2017).Effect of antihipoglycemic Sechium edule Jacq. Swartz. Etanol extract on histopathologic changes in hyperglycemic Mus musculus L. Indonesian Journal of Medicine (2017), 2(2): 86-93 https://doi.org/10.26911/theijmed.2017.02.02.02

Skovsø S (2014). Modeling type 2 diabetes in rats using high fat diet and streptozotocin. J Diabetes Investig. 5(4): 349-358.

WHO (2016). Diabetes Country Profiles. Available at http://www.who.int/diabetes/country-profiles/idn_en.pdf?ua $=1$.

Wu CH, Ou TT, Chang $\mathrm{CH}$, Chang XZ, Yang MY, Wang CJ (2014). The polyphenol extract from sechium edule shoots inhibits lipogenesis and stimulates lipolysis via activation of AMPK Signals in HepG2 Cells. Journal of Agricultural and Food Chemistry, 62(3): 750-759. doi: 10.1021/jf404611a

Zhang X, Jin Y, Wu Y, Zhang C, Jin D, Zheng Q, Li Y (2018).Anti-hyperglycemic and anti-hyperlipidemia effects of the alkaloid-rich extract from barks of Litsea glutinosa in ob/ob mice. Scientific Reports, 8(1). doi: 10.1038/s41598-018-30823-w 